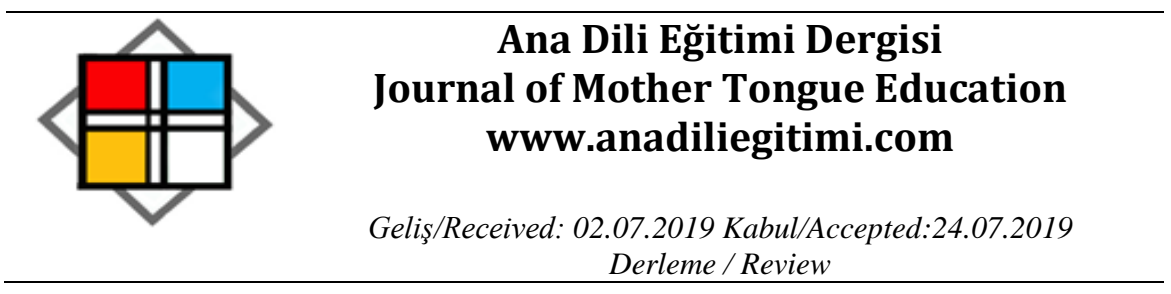

\title{
Beş Hececiler'den Enis Behiç Koryürek ve Makedonya
}

\author{
Zeki GÜREL*
}

Öz

"Beş Hececiler"den Enis Behiç Koryürek, Makedonya başta olmak üzere Balkanların en sıkıntılı olduğu zamanda çocukluğunu ve ilk gençlik yıllarını Üsküp’te Türk-İslâm kültürü içinde geçirmiştir. Enis Behiç, 12 Mart 1892 tarihinde İstanbul'da doğdu. Babasının asker oluşundan ötürü Enis Behiç'in çocukluğu Makedonya'da geçmiş, ilk tahsilini hususî olarak evde yapmış ve bizzat babası tarafından okutulmuştur. Bir ara özel öğretmenlerden de dersler almışsa da İdadi tahsilinin büyük kısmını Selanik ve Üsküp İdadi mekteplerinde gördükten sonra 1909'da İstanbul'a gelerek son sınıfı İstanbul Lisesinde tamamlamış ve 1910 yılında da mezuniyet diplomasını almıştır. Şair, öğretmen, diplomat, bürokrat ve mutasavvıf kimliğiyle dikkatleri çeken Enis Behiç Koryürek 18 Ekim 1949'da Ankara'da vefat etmiştir. Türk-Macar dostluğunun gelişmesinde, Macaristan'daki Gül Baba Türbesi'nin restore edilerek yeniden ziyarete açılmasında büyük hizmetleri olmuştur. 1909-1910 yıllarında Üsküp'te yayımlanan "Yıldız" dergisinde Enis Behiç Koryürek'in şiiri ve ona ithaf edilmiş şiirler de bulunmaktadır. Biz bu bildirimizde, Çocukluğunun ilk gençlik dönemine kadar olan kısmını Balkanlarda, özellikle de Üsküp'te geçirmiş olan “Beş Hececiler”den Enis Behiç Koryürek adlı şairimizin hayat hikâyesini ve eserlerini uzun uzadıya anlatacak değiliz. Meraklıları edebiyat tarihlerinden ve Enis Behiç için yazılan kitaplardan, bizzat Enis Behiç'in kendi eserlerinden istifade ederek bu meraklarını giderebilirler. Biz onun Makedonya günleri üzerinde özellikle yoğunlaştık.

Anahtar Kelimeler: Enis Behiç Koryürek, Beş Hececiler, Makedonya, Üsküp

\section{Enis Behiç Koryürek of Five Syllabists and Macedonia}

\begin{abstract}
Enis Behiç Koryürek, one of the poets of Five Syllabists, was born in March 12, 1892 in Istanbul, and spent his childhood and early youth with Turkish-Islamic culture, in Skopje, during the tough times of Balkans. Due to his father's assignment in military, he spent his childhood in Macedonia and was primarily home-educated, by his father. However, he took some courses from private teachers, his high school education was mostly in high schools of Thessaloniki and Skopje. After that he came to Istanbul in 1909. He completed his high school degree in İstanbul and got his graduation diploma in 1910. He came forward with his various identities; such as poet, teacher, diplomat, bureaucrat, and sufic and died in October 18, 1949 in Ankara. Enis Behiç Koryürek played a great role in development of Turkish-Hungarian friendship and restoration of the tomb of Gül Baba. There are number of poems in Skopje centred journal Yıldız, which are either written by him or dedicated to him in between 1909 and 1910. This work particularly focused on Enis Behiç Koryürek's days in Macedonia and the role of those days on his works.
\end{abstract}

Keywords: Enis Behiç Koryürek, Five Syllabists, Macedonia, Skopje

\footnotetext{
* Dr. Ögr. Üyesi, Gazi Üniversitesi, Gazi Eğitim Fakültesi, Türkçe ve Sosyal Bilgiler Eğitimi Bölümü, Ankara, zekigurel@yahoo.com, ORCID: 0000-0001-5129-7033
} 


\section{Giriş}

Yedi yıllık bir ayrılıktan sonra gurbetten vatana dönüşünde "Ey Türkeli!.." başlıklı şiirinde:

Ey Türkeli, ben uzaktan gelen yorgunum.

Dinle beni, ben de senin bir öz oğlunum

Geceleyin çölde yalnız kalan yolcu bir

Solgun ışık fark edince nasıl sevinir,

Nasıl ümidini bağlarsa ona,

Ben de öyle yadelinden baktım vatana.

Sen uzaktın benden, fakat kalbim senindi,

Ey Türkeli, hasretin tâ ruhuma sindi. diyerek; "hubbil vatan min el iman" (vatan sevgisi imandandır) hükm-i katisini bize hatırlatan Enis Behiç Koryürek, babasının görevi sebebiyle çocukluğunu ilk gençlik yıllarına kadar Makedonya'da yaşamış bir şair ve devlet adamıdır. Enis Behiç, 12 Mart 1892 tarihinde İstanbul'da anne dedesi Albay Said Bey'in Aksaray'daki evinde doğdu. Babası askerî Doktor İsmail Behiç Bey, annesi aslen Trabzonlu Fâika hanımdır.

Babasının asker oluşundan ötürü Enis Behiç̧'in çocukluğu Makedonya'da geçmiş, ilk tahsilini hususî olarak evde yapmış ve bizzat babası tarafından okutulmuştur. Bir ara özel öğretmenlerden de dersler almışsa da İdadi tahsilinin büyük kısmını Selanik ve Üsküp İdadi mekteplerinde gördükten sonra 1909 'da İstanbul'a gelerek son sınıfı İstanbul Lisesinde tamamlamış ve 1910 yılında da mezuniyet diplomasını almıştır.

Onun şiire başlaması Üsküp İdadisinde talebe iken olmuştur diyebiliriz. Bizim tespit edebildiğimiz yayımlanan ilk şiiri 1909-1910 yıllarında Üsküp'te çıkan "Yıldız" dergisinin 8. sayısında yer almıştır. "Telhî-yi Hayât" başlıklı bu şiirini Üsküp Idadi Mektebinden arkadaşı Saffet Örfi'ye ithaf etmiştir:

\section{Telhî-yi Hayât}

-kardeşim Saffet Örfi'ye-

O gün, evet büyük annem hayatı terk ederek

Bıraktı bizleri mahzûn u dâğdâr-ı elem

Sönük nazarları gûyâ ifâde eyleyerek

Fânî âlemi, efzûn olurdu âh... giryem 
Beş Hececiler'den Enis Behiç Koryürek ve Makedonya

Kemâl-i hüzn ile tâbût-ı giryedârını biz

Mezarlığa götürüp, âh... namazını kıldık.

Türâb-ı kabrini tartîb ederdi gözlerimiz

Onun firâkı ile hep yanardık, ağlardık

O yevm-i pür-kederin yâd-ı mâtem-engîzi

Olur, elem-res-i kalbim vakit vakit şimdi

Gözüm önünde onun vech-i şefkat-âmizi...

Nedir hayat ki bütün halk ona perestiş eder

Bugün değilse yarın biz de terk-i cân ederiz

O şu'le-i nazar-efrûz ecel gelince söner (Koryürek, 1910: 13).

"Yıldız" dergisinin koleksiyonunu karıştırınca görüyoruz ki, Enis Behiç bu şiirini derginin 6 . sayısında Üsküp İdadi'den arkadaşı Saffet Örfi'nnin kendine ithafen yazdığı “Mez'ar-ı Mâderde Bir Nevâyı Garîbâne" başlıklı şiirine cevap olsun diye yazmıştır:

MEZÂR-I MÂDERDE

BIR NEVÂ-YI GARÎBÂNE

-Kardeşim Enis Behiç'e-

Vâlidem! Sen ne haldesin şimdi

Hâke oldun mu münkalib şimdi

Kim bana şevkat eylesin şimdi?

Şimdi sensiz şu âlem-i fânî

Ser-te-ser âdetâ olur zindan!

Bence mevt ü hayattır sübhan

Öyle bî-vâye kalmadan her an!

Nerdesin? Gel, mihr-ibânım gel!..

Âh! O mâtem günü ne muzlim idi:

Gâib etmiş idim seni annem!

Tâ ki arşa çıkardı efgânı, 
Ağlıyordu dil-i hazînim o dem

Nerdesin? Gel, mihr-ibânım gel!..

Vah, gaybûbetin zamanında

Sûz-ı firkatle bî-mecâlim ben

Derd-i hasretle pür-melâlim ben

Hayf, bî-kes beni bıraktın sen

Tâ ebed firkatin zamanında..

Seni andıkça eşk-i rîzânım

Ye's ile her zaman da giryânım

Hüzn ile dâima perişânım

Nerdesin? Gel, mihr-ibânım gel!..

Vâlidem, vâlidem! Bıraktın âh,

Kimsesiz, lânesiz beni, ey vâh!

Ben kime şimdi, yalvarıp durayım?

Hâlimi hangi ademe sorayım?

Böyle mi kısmet eylemiş Allah?

Nerdesin? Gel, mihr-ibânım gel!..

Kim bilir hangi bâğ-ı cennette

Hangi kâşâne-i sa'âdette

Hangi gülşende, gülistanda bu dem

Kâm-rânsın, ferahlasın annem!

Ben ise kûşe-i sefâlette,

Dûzah-ı âfet ü feklakette

Ağlarım kanlı yaş ile pür-gam!

Nerdesin? Gel, mihr-ibânım gel!..

İşte kabrinde şimdi ağlıyorum, 


\section{Beş Hececiler'den Enis Behiç Koryürek ve Makedonya}

Kalbimi giryelerle dağlıyorum!

Aç şu âgûş-ı bî-riyânı bana,

Al şu bî-çâre oğlunu oraya!

Hâb ü râhatta dâima kalayım,

Kâmı dünyadan ol zaman alayım

Hâsıl olmaz mı emel acaba:

Celb ile kabre eylemek ihyâ?

Nerdesin? Gel, mihr-ibânım gel!..

Artıyor dikdeki melâl her bâr

Dâimâ başka türlü hüznüm var...

(Üsküp İâdî talebesi) (Betin,1910:13)

Çocukluğunu geçirdiği Balkanların Enis Behiç'in vatan ve millet algısında farklı bir yerinin olduğunu şiirlerini incelediğimizde görmemiz mümkündür. Onun ilk şiirlerinden birini Balkan Harbinde şehit düşen arkadaşına ithaf etmesi de bu hükmümüzü doğrular niteliktedir. "18 Eylül 1326'da yazılmış 'Barbaros!' adlı şiir de, daha sonra Balkan Harbinde şehit düşen arkadaşı Ziya'ya ithaftır ki üzerinde dikkatle durulmağa değer. Servet-i Fünun ve Fecr-i âti şairlerinin kullandığı aruz vezni kullanılarak, Arap, Acem kelimeleri bol ağdalı bir dille yazılmış bu manzumede, onlarda hiç rastlanılmayan bir mevzu işlenmiştir. Bu manzumede, hem ana hem baba tarafından asker olan bu cismi zaif, ruhu kavi ve yüce, cürmü küçük, yüreği kor şairin millî tarihimizin deniz arslanına, millî övünç kaynaklarımıza daha o çağlarda mevcut bağlılığı görülmektedir." (Tevetoğlu, 1951:XI)

Balkan Harbinin genç şairin ruhunda yarattığı acı ve kopardığı fırtınalar, daha sonra Umumî harp ile devamedegelmiştir. O bu duygularla kaleme aldığı yazı ve şiirlerini "Şehbal" ve "Donanma" mecmualarında yayımlamıştır. Onun bir şair olarak haklı bir şöhret kazanması ve edebiyatımızdaki yerini alması İstanbul Lisesi yıllarına rastlar. İmtihanı kazanarak girdiği Mülkiye Mektebinden mezun olduğu (1913) yıllarda ise artık tanınan bir şairdir.

Yukarıda şiirinden ve elyazısından bir örnek verdiğimiz Enis Behiç Koryürek'le ilgli olarak Türk Edebiyatı Tarihi incelendiğinde görülecektir ki Enis Behiç, Servet-i Fünuncular arasına katılmamış, Fecri âticiler arasına da çok sonra katılmış ve çok kısa bir müddet onlarla birlikte hareket etmiştir. Onun adı daha çok "Beş Hececiler"le birlikte anılmıştır. "Beş Hececiler. Hecenin beş şairi diye anılan Orhan Seyfi Orhon (1890-1972), Enis Behiç Koryürek (1891-1949), Halit Fahri Ozansoy (1891-1971), Yusuf Ziya Ortaç (1895-1967), Faruk Nafiz Çamlıbel (1898-1973) beşlisi için kullanılan bir ibare (Gürel,2018:30). 
Illk şiirlerini aruzla yazmalarına rağmen, bu beş kişinin 'hececiler' diye bilinmelerinin en büyük sebebi, önemli şiirlerini heceyle yazmaları, hece vezninin ülkemizde itibarda olduğu bir dönemde, aynı zaman diliminde yaşamış olmalarıdır (Karataş, 2007:68)

Enis Behiç Koryürek'le ilgili bugüne kadar en kapsamlı araştırmayı yapıp yayımlayan Dr. Fethi Tevetoğlu bu konuda şu yorumu yapmaktadır: “En mühim nokta bu eserlerinde Enis Behiç'in bugünkü anlayışımızda bir milliyetçi bulunuşudur. Vatanın ve milletin ızdırabı, Namık Kemal'in ruhundaki gibi ulvî, Fuzulî́nin yanık bağrındaki kadar ateşli ve derin olarak Koryürek'ten daha o zaman dökülmüştür. Böylece, aynı edebi sınıftan diye anılan çağdaşları ile, şiirlerinin mevzuları bakımından büyük ve takdire değer bir ayrılık göstermiş, çok zor bir sahada başarı elde etmiştir."(Tevetoğlu, 1951:XVI)

Enis Behiç'in sosyal muhitinde ve edebiyat dünyasında yer alan isimlerden Ziya Gökalp'in onun şiir anlayışında etkisi büyük olmuştur. Bu konuda Enis Behiç'in kendisine bir kulak verelim, bakınız neler söylüyor: “Ben Gökalp ile ilk önce Balkan Savaşından sonra tanıştım. O zaman koca Rumeli’yi elimizden aldırmıştık.; Edirne bile düşmüştü. Türk ordusu hiç eşi görülmemiş bir bozgunla darma dağın olmuştu. Bir genç şair, Mülkiye Mektebinde yetişmekte olan bir genç, yurdunun bu kanlı ve zehirli günlerinde varlığını saran ve sarsan derin acıları, o onulmaz ve unutulmaz yasları Namık Kemal'in ruhuna armağan ettiği bir (ballad) ile ağlamıştı. Bu baladın adı (Vatan Mersiyesi) idi. Üslubu, vezni, ahengi Tevfik Fikret usulünce idi. O vakitler, 'Şehbal' mecmuasında çıkan bu şiirle adını ortaya atan bu genç şair, her yandan birçok alkış toplayıvermişti. Biraz sonra Edirne'nin tekrar Türklerin eline geçmesi, Selimiye Camiinin minareleri arasında yine Al Bayrağımızın dalgalanması için kendini toplayan ordu ileriye atıldı. İşte o vakit, o genç bir de "Ey Meriç!" adında bir şiir yazmıştı. Bu da aruz usulü ile yazılmıştı. Fakat o genç şair bu yazısını herkesin, herkesin okumasını istiyordu. Bu sebeple yazısını bir salon mecmuası olan "Şehbal"e vermeyerek "Halka Doğru" adı ile çıkan bir küçük haftalık risaleye vermek için, o zamanlar Nuruosmaniye'de bir küçük evde bulunan gazete idarehanesine gitti. Alt kattaki küçük odaya girince tıknaz, orta boylu, ağır halli bir adam onu tanıyarak: -Buyurunuz, Enis Behiç Bey! Diye karşıladı ve gülümseyerek yer gösterdi. Ben bu zatı şahsen tanıyordum. Bu Gökalp idi. Kendisine şiirimi verdim. Dikkatle, ağır ağır okudu. Pek güzel, risalemize basalım, dedi. Fakat siz eğer bu lûgatları, bu aruz vezinlerini, bu eski tantanalı sözleri bıraksanız da millî ölçülerimizle, hece vezinleriyle ve sade Türkçe ile, şu tatlı tatlı konuştuğumuz Türkçe sözlerle, yüreğinizden koptuğu gibi sıcak ve cana yakın şiirler yazsanız bundan pek çok fazla muvaffak olur ve edebiyatımızda tam yerinizi alırsınız. Bu üslûp, bu ifade yarının ifadesi değil. Yarın bunlar okunmayacak. Siz yalnız bugünün şairi olup ta yarının şairi olmak istemiyor musunuz?

Ben bu sözler üzerine biraz sıkıldım; sesim hafifçe titredi, çok gençliğin verdiği utanca yine çok gençliğin verdiği atılganlığı da katarak o güne kadar gördüğüm hece vezni ile yazılmış şiirlerin ahenksizliğini ileri sürdüm ve bundan dolayı hece vezninden kaçındığımı söyledim. Gökalp güldü: 


\section{Beş Hececiler'den Enis Behiç Koryürek ve Makedonya}

—Hece vezni işlenmemiştir. Henüz sizin gibi genç şairlerin eline geçmemiştir. Ondan dolayı bu sazın ahengini siz kuru buluyorsunuz. Hele siz bir deneyiniz; temiz Türkçemizle birkaç parça yazınız; bakın, nasıl muvaffak olacak ve bu yeni çı̆̆ırı nasıl sevecek, benimseyeceksiniz.

Gökalp öyle inandırıcı ve kuvvet verici bir tarzda, fakat hiç de jest yapmaya lüzum görmeksizin öyle sürükleyici bir ağır eda ile söylemişti ki "Halka Doğru" idarehanesinden biraz sonra çıktığım vakit içimden: Niçin olmasın, bir kere denemeliyim! Diyen sesi artık düşüne düşüne dinliyor ve bu sese uymak istiyordum. Birkaç gün geçince "Hodbin" adını taşıyan ilk hece vezinli şiirimi yazdım. Bu yazım çok muvaffakiyet kazandı, çok beğenildi. Bunun üzerde, hep temiz konuşma Türkçesi ile şiirlerim birbirinin ardınca doğdu. Ve böylece işte bu güne değin, yirmi iki yıldır hep o yolda, Gökalp'in bana gösterdiği yolda yürüyerek, eyi- kötü, azçok bugünkü gençlerin hep bildikleri yazılarımı yazdım. Demek oluyor ki, benim şairliğimde Gökalp'in irşadının büyük tesiri olmuştur.. Bunu şimdi sizlere söylerken, o zamanlar beni durmadan bu yolda çoşturan rahmetli Ömer Seyfeddin'in adını da ayrıca anmalıyım. Bunların yanında Ali Canib ve Mehmed Ali Tevfik adlarını da ozanlı̆ımın kuvvet verici değerli dostları diye teşekkürle anarım Gökalp için $O$, bir şair değildir diyenlere ben kendimi ve benim gibi, benim kuşağımdan olan öteki şair arkadaşlarımı göstererek derim ki: Gökalp kendisi şair olmasa bile şairler yetiştirmiş̧tir. Türk edebiyatının gidişinde derin tesiri olmuştur. Şiirimizin duru ve parlak seslerini onun alık verdiği millî sazı çalarak duyduk ve duyurduk." (Koryürek, 1934: 172)

Türk Edebiyatı Tarihine "Beş Hececiler"den biri olarak geçen Enis Behiç Koryürek, 26 Ekim 1934'de Ankara Halkevinde Ziya Gökalp'in edebiyat ve şairlik bakımından değerini anlattığı bu konuşmasında daha sonra sözü; Üsküplü şair Yahya Kemal Beyatlı'ya getirerek de şunları söylemiştir:

“Gene o çağlarda Paris'ten yeni dönmüş bir şair vardı ki, bu da bize temiz, işlenmiş billur gibi çınlayan mısralarla Divan edebiyatının Nedim'in Acem halılarından bir koridor döşemeye başlamıştı. Bir gün Gökalp bu Paris’ten gelen şairin tuttuğu yola ilişti; ona:

Harabisin, harabatî değilsin

Gözün mazidedir, âti değilsin

Diyerek onun da millî çığırda ozanlık etmesini istemişti. Buna karşılık o şair:

Ne harabî, ne harabatîyim;

Kökü mazide olan âtiyim

Demişti. Doğrusu bu cevap, nüktece, söynenişce Gökalp'in sözüne karşı koyacak parlaklıktaydı. O zaman çok hoşa gitmişti." (Koryürek, 1934:173)

Enis Behiç Koryürek'in Üsküp'te yayınlanan "Yıldız" dergisinde "Kirli Dudaklar" başlıklı bir de hikâyesi yer almıştır: 


\section{"Kirli Dudaklar"}

Bir akşamüzeri idi. Güneş cemâl-i âteşîni şuaat-ı zerrîniyle yaldızladığı gârâm-âlûd pembe, turuncî, sünbülî bulutların, ufuklarla lâyetenahî mînâ-fâm tülleriyle örterek son lemaatını son tebessümlerini ibzal ediyor, hücre-i zifafa giden bir nev-arûs-ı işvebaz, bir peri-i hüsnüan gibi gözler beni süzerek hâbgâhına çekiliyor. Köyün şimâl-i şarkîsinde bulunan bir ormandan nebeân ile gah dağların hafâ gah âğûş-ı nazından süzülüp uzak bir bezm-i aşkın tahiyyât-ı neşvedârıyla dem-sâz oluyor mütecessisine bir terâne-i derûnî ile geçen gah şems-i tâbân, o duhter-i cilvekârın nigâh-ı tecessümünden saklanmak isteyerek tabiatın ihmâl-perverâne teşkil ettiği yeşil korucukların arasından feşâfeş hafif dumanını işittirmekten muhteriz bir dinler-i sevdâ-çîn gibi yavaş yavaş kıvranan ince bir ırmak vakt-i gurûbta semavattan inerek rûh-ı arzı titreten elhân-ı manev^yyeye sâmia-nevâz zemzemelerle mukabele ediyor. Sanki biraz sonra tulû eyleyecek olan kamerin hissiyât-ı sevdâperestânesini, hevesât-ı gârâm-perverânesini daha ziyade tahrik ederek bir an evvel arz-ı dîdar eylemesi için hazin hazin aşk neşideleri okuyordu...

Sabahtan beri roman okumak, resim yapmakla yorulmuş olan zihin ve fikrimi dinlendirmek ve tarlalardan avdet eden köy halkını seyreylemek üzere ellerimi pantolonumun ceplerine sokarak ve rehavetkârane adımlarla yürüyerek köyün ortasında bulunan meydanlığa kadar geldim Ötede beride küçük küçük tepecikler husule getiren zümrüdîn ot yığınlarından biri üzerine asilane oturdum. Meydanın ortasında püskülsüz fesli, sarı kırmızı, mor mintanlı, yemenili, ayakları çıplak beş on çocuk bağrışarak ufak bir sebepten dolayı yekdiğerlerine küfürler savurarak, birbirlerini hilebazlıkla yalancılıkla itham ederek koşuşuyorlar, oynuyorlardı.

Daha ötede gözlerinde -çiftçilikle geçen- asûde bir hayatın son lemaat-ı mesûdanesi parlayan aksakallı, beli bükülmüş bir pîr-i sâlhude kulübenin kapısı önünde iri bir taş üzerinde oturmuş, bî-renk buruşuk, yanaklarını yekdiğerine temas ettirircesine bir şiddetle -kendisi gibi ihtiyar- boyası dökülmüş ve uzun bir çubukla cığara içiyor. Ara sıra eski şalvarının yan cebinden çıkardığı siyah küçük tahta kutudan bir tutam enfiye alarak burun deliklerine kemâl-i itina ile yerleştiriyor, sonra çocuklara bakarak kendi devre-i sabâvetini der-hâtır eyleyip hafifçe gülümsüyordu. Ben bazen-eyyâm-ı hayatın son demlerine gelmiş olan bu saldîde ihtiyara bazen henüz kanları asabiyet-i tıflâne ile kaynayan, mütemadiyen, bağrışarak sıçrayan koşan, dehân-ı masumanelerini bir çok şüt^^m-ı müstehcene ile telvîs eden çocuklara, bu terbiyesiz mahlûklara, gah gurûbun elvân-ı gûn-agûn-ı âteşîniyle kızaran asumana, gah korucukların sâye-i zümrüdü altında kalan ırmağın reng-i hazin-i memakîrânesine bakarak ara sıra gurûb-ı şemsi selamlayan kurbağaların feryadlarına vakf-ı sem ederek tahayyilata dalmışıım ki; yakınımdan gelen ince rûh-nevâz bir kahkaha beni ikaz etti. Başımı çevirdim bu, beş altı yaşında bir çocuktu. Sarı lepiska saçlarının bir kısmı omuzlarına kadar düşerek nazar-firîb lüleler, bir kısmı da çîn-i pâki üzerine dökülerek kaşları üstünde altın halkalar husule getirmişti. İnce samur kaşları 


\section{Beş Hececiler'den Enis Behiç Koryürek ve Makedonya}

beyaz kalkık bir vaziyette bulunarak latif bir intiha peyda eylemiş ve nısfı saçlarının sâye-i zerrîni altında kalarak saklanmıştı. Gözleri, semanın reng-i kebûdîsini tanzîr eden koyu mavi, tahrirli gözleri sanki birer matla-ı masumiyet idi. Kaşları gibi samur uzun hirpikleri ile müzeyyen olan o güzel gözlerden o iki matlaI masumiyetten süzülen nazarlar ise kendi kalb-i tıflânesi kadar saf! Bu iki çeşm-i laciverdî arasında ince nazik bir burun! Hele ağzı! Bunu tasvir için yalnız -yeni açılmış bir gonca- demekten başka söz bulamıyorum sonra bütün bu güzellikleri cem eden pembe tombul bir çehre. Diğer köy çocukları gibi kırmızı bir mintan, "nimten" mavi bir donla iksa edilmiş olan bu ferişteh-i cennet, bu timsâl-i zî-rûh-ı masumiyet otlar üzerine bağdaş kurarak oturmuş, sanki tebessüm için yaradılmış olan kiraz dudakları nîm-küşâde bir hâlde arkadaşlarını syrediyor, mini mini gül-renk ve tombul ellerini çırparak gülüyor, bütün sâfiyet-i kalbiyesi ve bütün masumiyet-i vicdâniyesiyle mütamadiyen gülüyor, ince, rûh-nevâz kahkahalar salıveriyordu. Bu levha-i masumiyeti görünce bilâ ihtiyar:

İşte dedim. Bütün bu terbiyesiz çocuklar arasında bir melek!.. Bir müddet bu güzel çocuğa, bu meleğe baktım doya daya baktım. Onun tıflâne handeleri ruhuma küşâyiş veriyordu. Nihayet dayanamadım; yavaşça yaklaşarak bin türlü ihtirazlarla o gül çehreden, o pembe, Nermin yanaklardan bir buse aldım. Birden başını anif ile çevirdi, benim bu nevâzişimden hiddetlenmişti. O la'l-gûn dudaklarını bir tavr-ı küstahâne ile büktü, o semalar kadar saf olan koyu mavi gözlerini tevbîh-âmiz bir surette büzerek küçülttü. O güzel vech-i gülfâmı bir işmi'zâz-ı muhakkirâne ile çirkinleşti. Eyvah... Bir an evvelki levh-i melekâne şimdi zîr ü zeber olmuştu. Bütün bu terbiyesizliklere zamime olmak üzere arsızcasına bağırdı: “Çekil oradan... Pis, mırdar! Ve yalnız tebessüm için yaratıldığını zannettiğim o küçük ağızdan birlaç yaramaz kelimeler fırlattı. O ince dudaklar o yeni açılmış gonca bu mırdar sözlerle kirlendi. Bir manzara-i levs-âlûd peydâ etti. Ben melek zanneylediğim bu küçük mahlûkun birdenbire tebdîlinden kalbim kırılmış adeta teessüfümden ağlamak derecesine gelmiştim. O nevşüküfte bir goncaya benzeyen güzel ağza, o lâl-gûn kiraz dudaklara, kemâl-i me’yûsiyetle baktım: O gonca-i terdeki tevaret sanki ağlıyor, o ince dudaklardaki letafet sanki paralanmış da kanlar akıyordu. Bu mülevves ve hacâlet-âmiz levhaya karşı gayr-ı ihtiyâri olarak ağzımdan şu sözler döküldü:

-Zavallı Kirli Dudaklar!..." (Koryürek, 1910:11-12)

Enis Behiç'in 1910'da Üsküp'te "Yıldız" dergisinde yayımlanan bu hikâyesi Üsküp çıvarındaki insanların hayatından bir kesit sunması ve şairin o zamanki dil ve sanat anlayışını göstermesi bakımından önemlidir diye düşünüyoruz.

"Yıldız" dergisinin geneline baktığımızda Türkçenin sadeleşmesi konusuna önem verdiğine şahit olmaktayız. Hâl böyle olduğu hâlde Enis Behiç'in hikâyesinde olduğu gibi diğer bazı kısa hikâyelerde de dil ve anlatımda Servet-i Fünûn Edebiyatının sanatkârane üslûbuna benzer bir üslûbla 
karşılaştı̆ı̆ızı da belirtmeden geçemeyiz. Bu konuda; "Yıldız" dergisiyle ilgili bir çalışma yapıp bunu yayına dönüştüren Dr. Abdülkadir Hayber ve Dr. Recai Özcan'ın yorumları şöyledir:

"Sonraları bir şair olarak ünlenecek olan Enis Behiç'in Kirli Dudaklar adlı hikâyesi de bu özellikleri taşıyan bir metindir. Hikâyenin ilk paragrafında yazar güneşin batma anının kelimelerle resmini çizer. Bu uzun tasvirden sonra kahraman etrafı seyre dalar. Çevresindeki insanları gördüğü gibi anlatmaya çalışır. Arkadaşlarıyla birlikte dışarıda oyunlar oynayan beş altı yaşında bir çocuğa bakar, gerçek ile hayalindeki görüntüyü birleştirmeye çalışır. Yazarın çocuk tasviri de yine bize Servet-i Fünûn yazarlarının saflık ve temizliğin sembolü olarak kullandıkları 'melekâne' bir çocuk resmini hatırlatır: 'Başımı çevirdim bu, beş altı yaşında bir çocuktu. Sarı lepiska saçlarının bir kısmı omuzlarına kadar düşerek nazar-firîb lüleler, bir kısmı da çîn-i pâki üzerine dökülerek kaşları üstünde altın halkalar husule getirmişti. İnce samur kaşları beyaz kalkık bir vaziyette bulunarak latif bir intiha peyda eylemiş ve nısfı saçlarının sâye-i zerrîni altında kalarak saklanmıştı. Gözleri, semanın reng-i kebûdîsini tanzîr eden koyu mavi, tahrirli gözleri sanki birer matla-ı masumiyet idi. Kaşları gibi samur uzun kirpikleri ile müzeyyen olan o güzel gözlerden o iki matla-ı masumiyetten süzülen nazarlar ise kendi kalb-i tıflânesi kadar saf! Bu iki çeşm-i laciverdî arasında ince nazik bir burun! Hele ağzı! Bunu tasvir için yalnız -yeni açılmış bir gonca- demekten başka söz bulamıyorum sonra bütün bu güzellikleri cem eden pembe tombul bir çehre.' Kahramanın tasvir ettiği bu çocuk görünüşü itibariyle bir meleği andırmaktadır, ancak gerçeklik görüntüden ibaret değildir. Güzellik bir bütün olarak algılanmadığı müddetçe görüntü bir yanılsamadan ibaret kalır. Nitekim melek görüntülü bu çocuğun ağzından çıkan kötü bir söz kahramanın 'hayalindeki' güzelliği, gerçekliğin çirkinliğine dönüştürür. Kahraman karşılaştığı 'çirkin' gerçeklik karşısında kalbinin kırılmış olduğunu hisseder. Gerçek ile hayal, tasavvur ile tahayyül dünyasının içinde yaşayan kahramanların gördüğü 'mahzun', 'zavallı', 'sefil' insanların hâlleri kısaca tasvir edilir birçok hikâyede. Bu özellikle de yukarıda belirttiğimiz gibi Servet-i Fünûn üslûbunun yansıması olarak değerlendirilebilir. Bunların yanında, Yıldız sütunlarında, 'halk diline' yakın, sıradan insanın okuduğunda anlayabileceği hikâyeler de vardır. (Hayber-Özcan, 2009:258-259).

Enis Behiç'in "Yıldız" dergisinde çıkan şiir ve hikâyesiyle ilgili olarak yine "Yıldız" dergisinde bir yazı yayımlanır. Mustafa Şekip (Tunç) imzalı bu yazı "Kirli Dudaklar" başlığını taşımaktadır. Yazısında Mustafa Şekip, Enis Behiç'in önce şiirine sonra da hikâyesine değinmektedir. Burada önemli olan bir başka husus da, Mustafa Şekip'in öğrencilerinden birinin yazılarıyla ilgili bir yazı kaleme almış olmasıdır. Eğitimci kimlik açısından oldukça önemli bir davranış olsa gerektir bu tavır. Söz konusu yazıdan bazı bölümler şöyledir:

“Bana mütalâa-ı sabâvetimin en rengîn sahifelerini hazırlayan Sa'dî Efendi'ye karşı beslediğim muhabbet ve ihtiram burada müşerref olduğum zaman tezâyüd etmişti. Yine bir gün odasında yan koltuğuna tefekkürâne oturmuş olduğu hâlde nâgehâni fırlattığı billûri zarafetleri dinleyerek mütelezziz 


\section{Beş Hececiler'den Enis Behiç Koryürek ve Makedonya}

oluyordum. Birden bire odaya mektep sıralarında tanıdığım zarifü'l endâm çalâk, âteşin bir genç giriyordu. Elindeki zarfı gözlerinde parlayan mânâ-yı iftihârı ketm edememekten mütevellid bir mahviyetle nîm-serbest bir hâlde "Yıldız" muharririne uzattı: Şüphesiz yine bir eser takdim ediyordu.

Takriben iki ay mukaddem bu sahifelerde büyük validesi hakkında Safvet Örfi Bey’e hitaben yazdığı-mütebeddilikten başka bir kusuru olmayan -şiir-i nezîhinin sedâ-yı mâtemi el-yevm dimağ ve kalbimde pür-hayât bulunduğu için beyaz zarfın sîne-i harîminde mahfî pür-şebâb yazıları okumak hevesiyle bir sabırsızlık gösteriyor bir taraftan da yazılan şiirin mevzuuna nüfuz etmek endişesiyle genç şairin gözlerini okumak istiyordum. Bu hâlimin farkına varan Sa'dî Efendi, derhâl bu sabırsızlığımı teskin etti. 'Kirli Dudaklar' şiir-i mensûrunu sahâif-i matbuata geçmeden okumak şerefine mazhar oldum Burada o sahife-i müstesnâ-i edebi tenkid edecek değilim. Belki kıraatime 'Zavallı Kirli Dudaklar!' diye hatime verdikten sonraki ihtisasâımı nakşedeceğim. Zira pek derindir.

Enis Bey burada küçük iki Nermin dudağın temâs-ı câzibe-dârına kondurulan bir buseden evvela bütün felsefe-i hüsnü hülâsa ediyordu. Her hüsün insanda bir ceriha bırakır, çünkü öptüm, fakat ceriha-dâr oldum diyor.

Evet, bahar da öyle değil mi? Bize az mı hüsünler getiriyor fakat çok geçmiyor dâmen-i simîniyle öyle zehr-nâk hatıralar, ufûl etmiş saadetler, nâtamam muaşakalar, ölümler bırakıyor ki bütün şebâbımızı zehirliyor, gözyaşlarımızı kurutuyor. Merhametsiz seneler geçtikçe sihr-i tesirini, iltifât-ı âşıkânesini azaktıyor. Nihayet bu zavalılı mukavemetten âciz vücutları ihtiyarlatarak vefasız kadınlar gibi bir köşe-i nisyâna atıveriyor! İşte hayat netice-i hüsn diyor!..

Enis Bey, pekâlâ bilirsiniz ki yarın yine aynı buse ve fakat başka bir mana ile hâr ü leb-rîz dudaklara konacak, yine cerihadar olacak, ağlayacak, inleyeceksiniz. Bu sefer her busenin arkasında bîrahm bir kadın tırnağı hissedecek, aldanacak, aldatacak fakat hüsne karşı kalbinizde kaynayan usâre-i aşk yine kurumayacak, o vakit bütün hâtırât-ı mâziye kâh zehr, kâh hayat olacak velhasıl saçlarınız ağardığı zaman bile bugün açılan ceriha kapanmayacak bilakis büyüyecektir.

Şiirinizde en dakîk usâre-i hayâtiye insanların her vakit insan ne melek ve ne de şeytan olduğunu, busenin akıbetinde hasrettiğiniz teessür ve infial ile o kadar güzel gösteriyorsunuz ki bu nokta selâmet-i tefahhus ve müşahedenize delalet ediyor. Bu cihet edebiyât-ı hâzırada pek mühimdir. On dokuzunu asıra gelinceye kadar hemen bütün üdeba insanları ya melek veya şeytan olarak tasvire sihirbaz değneğine benzeyen kalemlerinin bir darbesiyle insanın bütün tabiat-ı maddeye ve maneviyesini tebdîl ederek, istinadgâh-ı yegâneleri olan hayalleriyle etsiz kemiksiz insanlar, acib hayaller doğururlardı. Hâlbuki menşei (Didero) olup Balzak'ın dehâ-yı feyyâz ile Zola'lar (Emile Zola), 
Mopasan'lar (Guy de Maupasant), Flober'ler (Gustave Flaubert), Dode'ler (Alphons Daudet), Gonkur'lar (Goncourt Kardeşler) tenemmüv ederek bugün pek müsmir ve sayedâr bir şecere-i azîme teşkil eden (Hakikiyyun) romanlarında, her gün omuz omuza geldiğimiz, kanlı canlı adamları bütün beşeriyetiyle tasvir ettiler. Yaşattılar. Buna da ancak âsâr-ı eslâfı taklid etmeği hatırına bile getirmeyerek kendi müşahede ve tecrübelerinin en büyük bir vâsıta-i tahrîr ve tahlîl olduğunu anladılar ve anlattılar. Sizin de Kirli Dudaklar'da okuduğunuz romanları taklid etmeyerek, müşahede ve tahlîl-i şahsînizi hiçbir şeye feda etmediğinizi gördüğüm için istikbâl-i edebînizden pek ziyade ümitvar ve memnun oluyorum. Onun için hayatın müşahede ve tecrübeden başka salim ve hakîki bir âlet-i tefahhus ve ihâtası olmadığını bu günkü gibi kalemi her elinize aldığınız zaman unutmamanızı rica ederim. Çünkü her şeyin hakikatine ancak bu sayede vasıl oluruz. Bu fen artık bütün bedâhetiyle isbat etti. Fakat belki fikrinize: 'Fende hakikati anlarım lakin edebiyatta...' gibi bir tereddüt arız olur. Hayır, hayır, dünyada her şey fani yalnız hakikat bakidir. Hayal hiçbir vakit hakikatten iyi olamaz. Âsârı hakikâti meziyetten mahrûm olan üdeba vefatlarında eserlerini de beraber götürürler. Hatta bunlar ekseriya mürde-zâd olurlar. Ne hacet, bu bedâhete târih-i edebiyâtın herhangi sahifesi açılsa bir vâveylâ-yı hakikate şehadet eder. Bunun için Zola: 'yazın hakiki bir sahife ilelebet payidar olsun' diyor. Bu söz, bir muharririn hakikate mukârin olmayarak kütüphaneler dolusu yazdığı âsârın bile hemen kâmilen mevte mahkûm olabileceğini pek beliğ bir beyan ile ifham ediyor. Bakınız ki Dö Maupasant da ne diyor: 'Bir muharririn ehliyeti şahsiyetinden neşet eder ki bu da bir tarz-ı diğerde tefekkür, müşahede ve idrak ve muhakeme etmesidir. Sanatkâr vakayii ve hadisât-ı rûz-merre-i hayâtı tetkik ve tecrübe eder, neticede ya muvaffak olur veya sükût eder.

Evet, ne doğru; çünkü her insan muhiti, terbiyesi mizacı, sıhhati, tarz-ı tefekkürü, ihtisâsât-ı vesâiresi bir olmadığı için bittabi hayatı tarz-ı telâkkileri, vakâyi ve hadisâtı sûret-i müşâhedeleri bir olamaz. Binaenaleyh bir başkası gibi yazmaya savaşmak tabiatın kendisine bühtan etmiş olduğu alk ü zekâ ile, teessür ve tahassüsü istimal etmesin demektedir ki bu yolda yazılan eserler güzel kopyalardır. Eğer bir muharrir hakiki bir sanatkâr olmak isterse kendisini idrak ve müşahedede tasavvur ve tahayyülde zevk ve hisse serbest bırakmalıdır. Üsküp 5 Ağustos Sene 325” (Tunc, 1325/1910:11-12).

Enis Behiç'in de okuduğu Üsküp İdadi Mektebinden bugün geriye sadece giriş kapısının olduğu kısım kalmıştır. Diğer bölümler yıkılmıştır. Meraklılar, Sultan Abdülhamid döneminde 1891'de inşa edilen bu tarihi mirasımızı bugünlerde görmek istiyorlarsa Üsküp Şehir Parkının karşısında Karpoş Belediyesi hizmet binalarının/barakalarının arasına sıkısmış yapıyı ziyaret erebilirler.

Enis Behiç'in Makedonya Türk basınında yayımlanan son eseri ise; Makedonya'da Türkçe yayımlanan ilk çocuk dergisi olan "Pioner"in dördüncü sayısında yer alan "Yeni Yıl" başlıklı şiiridir. Bu şiirin şairin ölümünün birinci yıldönümü olan 1950 tarihine denk gelmiş olması da Üsküp'ün onu unutmadığının bir nişanı olsa gerek diye düşünüyoruz. 


\section{Sonuç}

Biz bu yazımızda, çocukluğunun ilk gençlik dönemine kadar olan kısmını Balkanlarda, özellikle de Üsküp'te geçirmiş olan Enis Behiç Koryürek adlı şairimizin hayat hikâyesini ve eserlerini uzun uzadıya anlatmadık. Meraklıları edebiyat tarihlerinden ve Enis Behiç için yazılan kitaplardan, bizzat Enis Behiç’in kendi eserlerinden istifade ederek bu meraklarını giderebilirler.

Türk Edebiyatı tarihini yazacaklara; bu yazı vesilesiyle bir hususu özellikle hatırlatmak isteriz: 1884'te Üsküp'te doğan ve 18 yaşında İstanbul'a göç eden, şiirlerinde ve yazılarında hem Türkiye'yi hem de Makedonya'yı yaşatan büyük Türk şairi ve düşünür Yahya Kemal Beyatlı, "Türkçenin çekilmediği yerler vatandır." Demişti. Edebiyat, malzemesi dile dayanan sanatsa eğer, Türk Edebiyatı Tarihi de ses bayrağımız Türkçenin dalgalandığı kültür coğrafyamızda Türkçe yayımlanan her dergiyi, kitabı ve yazıyı görmezlikten gelemez, gelmemelidir. Bu tespitimiz Enis Behiç Koryürek'in edebiyat dünyasını aydınlatırken ne kadar gerekli ise daha pek çok şair ve yazarımızın sanat ve fikir dünyasını aydınlığa kavuşturmak için de geçerli olabilir. Balkanların en sıkıntılı olduğu zamanda Üsküp’te Türk-İslâm kültürü içinde çocukluğunu yaşayan şair Enis Behiç Koryürek'in “Millî Neşide” başlıklı şiirini hep beraber okuyalım istiyorum:

Biz kimleriz?..Biz "Altay"dan gelen erleriz.

“Çamlıbel”de uğuldarız; coşar, gürleriz.

Biz öyle bir milletiz ki ezelden beri

Hak yolunda yalın kılıç, hep seferberiz.

"Zafer" bizim şaha kalkmış küheylânımız;

Atıldı mı durduramaz ne dağ, ne deniz...

Felâketler pençemizde oyuncak olur;

Yangınlarla bütün cihan alsancak olur.

Tanyerinden yıldırımlar saçan sesimiz

Gün batısı üzerinde şöyle duyulur:

Fırtınalar yoldaşıdır nâra salan Türk!

Hey koca Türk, Tanrısından kuvvet alan Türk!

Yürüyoruz, başımızda “Ay-yıldız"ımız

Genç, ihtiyar, kadın, erkek, oğul, kızımız...

Soyumuzda ne kahraman kardeşler vardır, 
Türkmen, Oğuz, Başkurt, Tatar ve Kırgızımız...

Demir dağlar delmiş olan "Bozkurt”larız ki

“Orkun" da var “Kül Tiğin”den kalma yazımız...

Hamlemizden yere geçer kanlı saraylar.

Bizce birdir gedalarla baylar, giraylar...

Medeniyet şimşeğinden gelir hızımız;

Sorma: Kimdir kanatlanmış bu genç alaylar?

Bunlar bütün nûra doğru akın eden Türk!

Hey koca Türk, uzakları yakın eden Türk!...

\section{Kaynaklar}

Betin, Saffet Örfî (1910). Mezâr-ı Mâderde Bir Nevâ-yı Garîbâne, Yıldız, Üsküp: 25 Mart 1325, (6).

Altıniş-Gürsoy B. (2006). Koryürek, Enis Behiç. Türk Dünyası Ortak Edebiyatı Türk Dünyası Edebiyatçılar Ansiklopedisi, 6, 65-67.

Gürel, Z. ve Altay S. (2018). Yusuf Ziya Ortaç'ın dikkatlerden uzak kalmış bir eseri: Şairin duası. Çıngı Dergisi, (51), 4-34.

Hayber, A. ve Özcan, R. (2009). Üsküp yıldız. Üsküp: MATÜsiTEB Yayını.

Karataş, T. (2007). Ansiklopedik edebiyat terimleri sözlüğ̈̈̈ 3. Baskı). Ankara: Akçağ yayınları.

Koryürek, E. B. (1934). Ziya Gökalp’ın Edebiyat ve Şairlik Bakımından Değeri. Ankara Halkevi'nde 26 Ekim 1934 tarihinde verilmiş olan konferans.

Koryürek, E. B. (1910). Telhî-yi Hayât, Yıldız, Üsküp: 5 Nisan 1325, (8).

Koryürek, E. B. (1910). Kirli dudaklar, Yıldız, Üsküp: 2 Ağustos 1325, (23).

Koryürek, E. B. (1950). Yeni yıl, Piyoner Gazetesi, Üsküp: 30 Aralık, (4).

Tevetoğlu, F. (1951). Enis Behiç Koryürek'den Miras ve Güneşin Ölümü, Ankara.

Tunç, M. Ş. (1910). Kirli dudaklar, Yıldız Dergisi, (24).

\section{Extended Abstract}

Introduction

Enis Behiç Koryürek is one of the poets of Five Syllabists along with Orhan Seyfi Orhon (1890-1972), Halit Fahri Ozansoy (1891-1971), Yusuf Ziya Ortaç (1895-1967) and Faruk Nafiz Çamlıbel (1898-1973).

Enis Behiç Koryürek, who draws attention with his identity as a teacher, statesman and diplomat, is under the influence of Servet-i Fünûn in the first years of his literary life. Later, he took part in the National Literature Movement and used syllable meter which is our national meter.

\section{Enis Behiç Koryürek and Macedonia}

Enis Behiç Koryürek lived in Macedonia during his father's military service there. Enis Behiç received his first education from private teachers at home and spent most of his school life in Thessaloniki and Skopje the capital of Macedonia. The fact that childhood and early youth were spent in Skopje affected Enis Behiç's personality and literary life.

The first publication of his poems is in the 8th issue of Yıldız magazine in Skopje. This poem is the answer to the poem titled as Mezar-ı Maderde Nevâ-yı Garibane written and published by Saffet Örfi, one of his friends. The Balkan War also influenced the personality and literary work of Enis Behiç. One of his first poems, Barboros, was dedicated to his friend Ziya, who was martyred in the Balkan War. 


\section{Beş Hececiler'den Enis Behiç Koryürek ve Makedonya}

Enis Behiç Koryürek, who was under the influence of Servet-i Fünûn in the first years of his literary life but did not join them, remained very short time among the Fecr-i Ati. He achieved his place in the history of literature with his works in the National Literature Movement. In the works of Enis Behiç, the influence of Namık Kemal and especially Ziya Gökalp is very important.

Enis Behiç spent part of his childhood and early youth in Skopje, capital of Macedonia, and published some of his first poems and stories in the magazine Yıldız in Skopje. His story titled Kirli Dudaklar was published in Yıldız magazine and attracted the attention of literary societies. Mustafa Şekip (Tunç) wrote a long article about this story and published it in Yıldız magazine.

Enis Behiç Koryürek's latest work published in Skopje is one year after his death. His poem "New Year" was published in 1950 in the children's magazine Pioner in Skopje. This is an indication that the people of Skopje have not forgotten Enis Behiç.

Result

In this article, Enis Behiç's life story was not mentioned, literary life and works at length. In the life and literary work of Enis Behiç Koryürek, we pointed out the effect of Macedonia and talked about his works published in Macedonia.

Seeing that most of the Turkish writers of the period, including Enis Behiç Koryürek, has published works during the period abroad, we want to emphasize that these works should also be taken into account while doing research on Turkish literature. 